\title{
Do Additional Bilateral Investment Treaties Boost Foreign Direct Investments?
}

\author{
Chang Hoon Oh* and Michele U. Fratianni**
}

* Chang Hoon Oh

Faculty of Business, Brock University

500 Glenridge Ave., St.Catharines

Ontario L2S3A1 Canada

Email: coh@ brocku.ca

Tel: 1-905-688-5550 × 5592

Fax: 1-905-378-5716

** Michele U. Fratianni

Kelley School of Business, Indiana University $140910^{\text {th }}$ Street, Bloomington, Indiana 47405 USA and

Department of Economics Università Politecnica delle Marche 60121 Ancona, Italy

Email: fratiann@indiana.edu

Tel: 1-812-855-3360 


\title{
Do Additional Bilateral Investment Treaties Boost Foreign Direct Investments?
}

\begin{abstract}
$\underline{\text { Abstract }}$
This paper finds that the stock of bilateral investment treaties (BIT) is subject to diminishing returns measured in terms of foreign direct investment flows. Diminishing returns are more pronounced among country-pairs that have not signed bilateral investment treaties but have their own BIT network than among country-pairs with their own bilateral investment treaties. For a given country's BIT network, a multinational enterprise finds more value in investing where a bilateral treaty is in place. This may suggest either stronger property-rights protection or greater latitude to use the host country as an export platform. Our subsidiary finding is that an index of a country's BIT network diversity appears to be a plausible explanation of the limiting force underlying the diminishing returns of the stock of BITs in a world where there is a mix between horizontally and vertically integrated multinational enterprises.
\end{abstract}

Keywords: bilateral investment treaty; foreign direct investment; gravity equation; network diversity

JEL Classification: F21; F53 


\section{Introduction}

Foreign direct investment (FDI) is now as much a central part of new regionalism as preferential trade agreements (PTAs) were in old regionalism (Ethier, 2001). ${ }^{1}$ Bilateral investment treaties (BITs) were designed to facilitate FDI flows from countries with abundant capital and skilled labor to developing countries. BITs have proliferated over the past fifty years, and especially in the past two decades, despite the difficulty of creating a multilateral FDI regime (Elkins et al., 2006). From 1989 to 2007 there has been a seven-fold increase in BITs (from 385 to 2,600). At the end of 2007, 22 countries had in place more than 50 BITs. $^{2}$ Governments now compete to attract FDI by offering a variety of incentives to investors (Wheeler and Mody, 1992).

The theoretical literature on the relationship between trade and FDI is variegated. FDI can move between similar (i.e., similarly endowed) countries, suggesting a channel of horizontal FDI (Markusen, 1984), or between dissimilar countries, suggesting a channel of vertical FDI (Helpman, 1984), or a mixture of the two, suggesting both horizontal and vertical FDI channels (Markusen and Maskus, 2002). Horizontal FDI implies substitution between trade and FDI: a fall in trade costs should induce a marginal switch from FDI to trade. Yet, the evidence shows that FDI has been growing while trade costs have fallen. This complementarity between exports and FDI has been explained in either of two ways (Neary, 2009). The first is that intra-bloc liberalization programs have encouraged the establishment of export platforms aimed at serving the entire bloc (e.g., Ireland in the European Union). The second is that declining trade costs have provided incentives of lower-cost multinational enterprises (MNEs) to acquire foreign higher-cost MNEs.

\footnotetext{
${ }^{1}$ Old regionalism emphasized border impediments to international; new regionalism has shifted attention to issues of deeper integration, that is of removing beyond-the-border market impediments.

${ }^{2}$ This list includes, among others, Argentina, China, Egypt, Finland, France, Germany, Italy, South Korea, Taiwan, and Turkey (UNCTAD, 2010).
} 
Quite independently of the theoretical view, BITs can reduce the expected cost of investing abroad and encourage FDI flows (Egger and Pfaffermayr, 2004). To be sure, there are studies, however, that have questioned the role of BITs in attracting FDI, claiming that the latter depends more on the political and economic system of the host country (Sornarajah, 1986) and on differences in cultural, political, and business practices between home and host and countries (Hoekman and Saggi, 2000) than on the creation of a formal legal structure. On balance, however, the literature has concluded that BITs exert a positive effect on FDI flows, at least from a static viewpoint.

This paper has two objectives. The first is to go beyond the static effects of BITs and empirically estimate the marginal effects of the stock of BITs on FDI flows. We find that BITs have marginal diminishing returns measured in terms of investment flows. The second is to provide a plausible explanation for this finding. We key on the country's BIT network diversity as a limiting factor underlying our main finding. We test the underlying hypothesis with a gravity equation on a large panel dataset covering inward FDI flows to 30 OECD countries and 118 nonOECD countries from 30 OECD countries over the 1980-2005 period. The gravity equation employs country-fixed, year-fixed, and country-pair random effects to overcome problems associated with a conventional gravity equation (Baldwin and Taglioni, 2007). We also check for the robustness of our findings in two alternative ways: with a country-fixed effect specification (Baier and Bergstrand, 2007) and a lagged variables specification (Frankel, 1997) to control for potential distortions due to sample self-selection and endogeneity of explanatory variables. Finally, we address the issue of zero values in the FDI data by employing a zero-inflated Poisson pseudo-maximum-likelihood estimator (PPML; Santos Silva and Tenreyro, 2006) and a zeroinflated negative binomial pseudo maximum likelihood regression (NBPML; Burger et al., 2009). 
This paper is organized as follows. Section 2 summarizes the theoretical and empirical literature on the pattern of FDI and BIT and links it explicitly to the literature on trade creation and trade diversion. Section 3 describes the data and empirical methodology. Section 4 discusses salient findings and provides robustness checks. Section 5 deals with BIT network diversity as a plausible limiting factor to the diminishing returns of the stock of BITss. Conclusions are drawn in Section 6.

\section{Investment Treaties and Foreign Direct Investment}

Historically, FDI has been subject to contractual and political hazards. Before the introduction of BITs, few credible mechanisms existed for the treatment of foreign investment. Customary international law, shortly the "Hull Rule," held that "no government is entitled to expropriate private property, for whatever purpose, without provision for prompt, adequate, and effective payment therefore" (Elkins et al., 2006, 813). BITs, on the other hand, were an important step in guaranteeing foreign investors fair and equitable, non-discriminatory, most-favored-nation and national treatment; offering legal protection of both physical and intellectual property rights under international law and investment guarantees, including expropriation, rules of compensation, and transfer of funds; and providing access to international means of dispute resolution (Guzman, 1998; UNCTAD, 2000; Desbordes and Vicard, 2009). ${ }^{3}$ Most importantly, foreign investors have the right, under international law, to sue the host government if it nationalizes the investment or alters the underlying regulatory structure (Hallward-Driemeier,

\footnotetext{
${ }^{3}$ The first BIT was signed in 1959 (enforced in 1962) by Germany and Pakistan. There was a lull in the 1960s and early 1970s driven by ideological debates on the standard of compensation for expropriation (Vandevelde, 1998). Then, developed countries became involved in the process: France with its first BIT in 1972, the U.K. in 1975, and the United States and Japan in 1977.
} 
2003). ${ }^{4}$ In sum, these contractual features have worked in raising the cost to host governments of reneging on their commitments and, thus, making these commitments more credible.

Academic research in investment agreements and FDI patterns is still at an early stage compared to the extensive literature on trade agreements and trade patterns. While there is some empirical evidence that BITs have increased bilateral FDI flows (Egger and Pfaffermayr, 2004; Neumayer and Spess, 2005; Egger and Merlo, 2007; Busse et al., 2010), no study has yet looked at the benefits of incremental BITs on country-pair FDI flows. In contrast, the literature on international trade and PTAs is rich with works dealing with the benefits and costs accruing to member and non-member countries from an expansion of PTAs, starting with Viner's (1950) classic work on trade creation and trade diversion and Bhagwati's (1991) extension of building vs. stumbling blocs. ${ }^{5}$ The present study applies the concept of trade creation and trade diversion due to PTAs to BITs in FDI.

The basic theoretical principle underlying a BIT is that it acts as a costly signal to foreign investors that a host country will honor the protection of property rights (Neumayer and Spess, 2005). The payoff for the host country is a larger flow of inward FDI from the country with which the BIT has been signed. In a multi-country setting, however, one needs to consider the effect of global competition for FDI. Assume three countries, with home country x signing a BIT with two host countries, y and z. The impact of the x-y BIT on x-y FDI flow will depend, not only the $x-y$ BIT, but also on the $x-z$ BIT and $y-z$ BIT. If the $x-z$ BIT is more attractive than the $\mathrm{x}$-y BIT, $\mathrm{x}$ can switch some FDI from $\mathrm{y}$ to $\mathrm{z}$. The result is that an additional BIT may not have the intended positive effect on the x-y FDI flow. One can also look at the effects of global

\footnotetext{
${ }^{4}$ International arbitration typically occurs through the International Center for Settlement of Investment Disputes or the UN Commission on International Trade Law (Elkins et al., 2006).

${ }^{5}$ As to more recent works: for the theory, see Krugman (1991), Yi (1996), Adnriamananjara (1999), and Fratianni and Pattison (2001); for empirical works, see Carrère (2006) and Fratianni and Oh (2009).
} 
competition for funds from the viewpoint of a host country that signs BITs with different home countries over time. The total number of BITs signed by a host country, NBITs, may imbed differences in the government's commitment to protect property rights of foreign investors by either vintage or origin. That is, while NBITs may be a positive function of competition on the sources side, bilateral FDI flows may not rise with NBITs.

There is also competition for funds between BIT and non-BIT countries. Other things the same, BIT countries should have larger FDI flows than non-BIT countries because of BIT's riskreduction benefits. But non-signatory countries could provide to the home country inputs that may not be available from non-signatory countries, such as an international supply chain network. To the extent that such inputs are unobservable and cannot be accounted for, NBITs can be associated with lower rather than higher FDI flows.

In sum, BIT may increase or decrease bilateral FDI flows by either reducing the cost of investing abroad or by increasing competition in host countries and the opportunity costs of funds in home countries. Thus, BITs can generate both FDI creation and FDI diversion; the net effect of these two forces becomes an empirical issue.

\section{Methodology and Data}

\subsection{Gravity Equation Specification}

Our statistical models use the gravity equation, which has been widely used in bilateral trade studies (see Fratianni, 2009 for a review), as well as in bilateral FDI studies (e.g., Egger and Pfaffermayr, 2004; Bénassy-Quéré et al., 2007; Head and Ries, 2008; Desbordes and Vicard, 2009; Guiso et al., 2009; Busse et al., 2010). The gravity equation model postulates that the FDI flow from home country $i$ to host country $j$ is directly proportional to the product of $\operatorname{GDP}_{i}$ and 
$\mathrm{GDP}_{j}$, and inversely proportional to the geographical distance separating the two countries. The model has been extended in a number of directions, including adding demographic, institutional, and cultural variables. Our testable FDI gravity equation is shown in Equation (1):

$$
\begin{aligned}
\ln F D I_{i, j, t} & =\alpha_{0}+\alpha_{1} \ln \left(G D P_{i, t}\right)+\alpha_{2} \ln \left(G D P_{j, t}\right)+\alpha_{3} \ln \left(P O P_{i, t}\right)+\alpha_{4} \ln \left(P O P_{j, t}\right)+\alpha_{5} \ln (D I S T)_{i, j} \\
& +\alpha_{6} C B O R D_{i, j}+\alpha_{7} C L A N G_{i, j}+\alpha_{8} C O L R_{i, j}+\alpha_{9} C U R U_{i, j, t}+\alpha_{10} R T A_{i, j, t}+\alpha_{11} O R T_{i}+\alpha_{12} O P E_{j} \\
& +\beta_{1}\left(B I T_{i, j, t}\right)+\beta_{2} f\left(N B I T_{i, j, t}\right)+\mu_{i}+v_{j}+\delta_{i, j}+\rho_{t}+\varepsilon_{i, j, t},
\end{aligned}
$$

where subscript $i$ denotes source country, subscript $j$ destination country, subscript $t$ year; $\alpha$ s and $\beta$ s are estimatable parameters; FDI denotes foreign direct investment flows and are expressed in nominal values, as suggested by Baldwin and Taglioni (2007); GDP and POP are gross domestic product and population, respectively; DIST is geographical distance between the country pair expressed in miles; CBORD is a dummy variable when the two countries have a common land border; CLANG is a dummy variable for a common language; COLR is a dummy variable for a shared colonial relationship; CURU is a dummy variable for a common currency; RTA is a dummy variable when the two countries are members of the same regional trade agreement; ORT is the home country's FDI orientation; OPE is the host country's FDI openness ; BIT is a dummy variable for the existence of a bilateral investment treaty; and NBIT is the number (stock) of bilateral investment treaties; more on this below.

There are two important econometric issues that we have to consider in estimating Equation (1): multilateral resistance and zero-value observations (Fratianni et al., 2010). On multilateral resistance, Anderson and van Wincoop (2003) argue that bilateral trade (but it also applies to FDI) flows depend not only on what goes on between a given country-pair but also between the country-pair and the rest of the world: bilateral trade flows are determined in a general equilibrium framework. These authors derive a gravity equation that includes bilateral 
and multilateral trade costs. The latter are a function of bilateral trade costs, countries' income shares, countries' price levels, and factors unobservable to researchers. Just as importantly, they are jointly determined and their omission creates a bias in the estimated coefficients. Anderson and van Wincoop correct for this bias by estimating " $n$ " non-linear equations. The procedure is very cumbersome and applicable when " $n$ " is very small. Baldwin and Taglioni (2007) have proposed an alternative using time-varying fixed effects $(\mathrm{FE}), \mu_{i, t}$ and $v_{j, t}$, and time-invariant $\mathrm{FE}$, $\delta_{i, j}$, for panel data, since the first two remove the time-series correlation and the third the crosssectional correlation. But this alternative has three drawbacks. The first is that the number of country dummies is unmanageable. The second is that serial correlation is only partially removed by $\delta_{i, j}$; nor can one utilize time-varying $\delta_{i, j, t}$ because the number of country dummies would catch up with the sample size. The third is that even though $\delta_{i, j, t} \mathrm{FE}$ could yield unbiased estimates, the researcher would not be able to estimate the impact of important time-invariant variables (e.g., distance) on $X$. For this reason, Carrère $(2006,231)$ proposes that $\delta_{i, j}$ be treated as a random effect (RE). This is the procedure we will use in the empirical work. In equation (1), in addition to $\delta_{i, j}, \mu_{i}$ and $v_{j}$ denote respectively home and host country FE, $\rho_{\mathrm{t}}$ time FE and $\varepsilon_{\mathrm{i}, \mathrm{j}, \mathrm{t}}$ a well behaved error term.

The second econometric issue arises from the presence of zero values. Zero-value observations and the fact that the log of zero is undefined make the data sample not randomly drawn. We will treat the zero-value problem in three alternative ways. The first is to change the dataset by adding one to those FDI flows that have zero-values. The second is to estimate equation (1) with a Poisson pseudo-maximum likelihood (PPML). Santos-Silva and Tenreyro (2006) argue that PPML is a superior alternative to a least square regression when errors are heterosckedastic. If the variance of these errors is correlated with the independent variables, the 
conditional expectation of the errors will no longer be zero and a linear regression produces biased estimates; under the same conditions, a Poisson regression produces estimates that are consistent and efficient in large samples (King, 1988). Just as importantly for us, PPML can treat the zero-value problem. The potential drawback of PPML, on the other hand, is overdispersion, emanating from the fact that the variance cannot be set independently of the mean. For this reason, and following Burger et al. (2009), we employ the third alternative of estimating equation (1) with a zero-inflated pseudo negative binomial pseudo maximum likelihood (NBPML).

\subsection{Data}

Our panel dataset consists of 148 countries and spans from 1980 to 2005 . We have annual bilateral FDI flows from 30 OECD countries to 30 OECD countries plus 118 non-OECD countries. The 30 OECD countries report their inward and outward FDI flows from other countries. If $i$ or $j$ are non-OECD countries, there is only one flow reported by OECD countries, which is what we use. For intra-OECD flows instead, the source reports both inward FDI flows by $i$ and outward FDI flows by $j$. Since the two numbers may differ, we use the average of the two flows. The average value of bilateral FDI flows in the sample is $\$ 439$ million. The highest bilateral value is the flow from the United Kingdom to the United States in 1999, \$111 billion; see Appendix A.

Information on investment treaties was collected from the United Nations Conference on Trade and Development (UNCTAD, 2010). BIT acquires a value of one if a given country-pair has signed a bilateral investment treaty. NBIT is the number of BITs. A distinction is made between NBIT for country-pairs that have BITs and country-pairs that do not. In the former case, 
NBIT is the sum of the total number of BITs of the home and host countries net of their bilateral treaties. In the latter case, NBIT separates the total number of BITs between the home and host countries. As an example, take three countries: home country A and host countries B and C. Country A has signed 10 BITs, country B 5 BITs, country C 4 BITs, and, in addition, A and B have a bilateral investment treaty. For country-pair A and B NBIT is 13 (i.e., $10+5-2=13$ ), whereas for country-pairs A and C and B and C, NBIT distinguishes between home BITs (10 for A and 5 for B) and host BITs (4 for C). This procedure intends to capture the incentives of FDI owners to invest in host countries that have a BIT network even though they have not signed a bilateral treaty with the home country. The separation of home and host country treaties recognizes the potential for different specializations, such as the home country emphasizing activities like product design, marketing and sales and the host country activities like sourcing and manufacturing. Approximately, 35 percent of the country-pairs in our sample have signed a bilateral BIT. The average NBIT for country-pairs with bilateral BITs is 27, of which 16 related to the home country and 14 to the host country. Germany holds the record of the country with the highest number of BITs (134 in 2005). Germany and China hold the record of the country-pair with the highest number of other BITs (180 in 2005).

Home country's FDI orientation is measured by home country's outward FDI as a percent of GDP and host country's FDI openness by inward FDI as a percent of GDP. These two variables are intended to capture policies directed at influencing unilateral FDI flows to and from partner countries because time-invariant country FE cannot capture the changes in FDI policies for both home and host countries. Their average values in the sample are, respectively, 7.5 and 6.9 ; their variances are six to seven times the size of the mean.

Finally, we have collected standard gravity equation control variables such as geographic 
distance, common land border, common language, common colonial relationship, common currency, and regional trade agreement (RTA). In our sample, six percent of country-pairs share a common land border, nine percent a common language, six percent a common colonial relationship, almost three percent the same currency, and 12 percent membership in the same RTA.

As an index of the diversity of the BIT network, we employ the Jacquemin and Berry (1979) entropy measure, computed as

$$
\text { Network Diversity } \mathrm{i}_{\mathrm{i}, \mathrm{t}}=\sum_{j} S_{j, t} \ln \left(1 / S_{j, t}\right) \text {, }
$$

where $S_{j, t}$ is the proportion of the $j$ th country's GDP in the total GDP of country $i$ 's BIT network in year t, and countries $i$ and $j$ have signed a bilateral BIT. A higher value of network diversity denotes that the network has either a larger membership or is more decentralized (diversified). If countries $i$ and $j$ have not signed a bilateral BIT, the value of network diversity is zero.

Table 1 provides formal description and sources of each variable; Appendix A gives descriptive statistics for these variables; and Appendix B lists the 148 countries included in the data. Our dataset has 21,099 non-zero observations of FDI flows and 11,474 zero-value observations. Thus, the zero problem is a potentially serious one.

[Insert Table 1 about here]

\section{Findings}

Table 2 reports the estimates of equation (1). Our specification includes year, home and host country FE and country-pair RE in line with our discussion above; standard errors of the coefficient are heteroscedastically consistent or robust. Zero-value observations are excluded and the sample size is 21,099 . Column one of the table reports the estimate of the impact of BIT on 
FDI flows, as it is done in other studies (Neumayer and Spess, 2005; Desbordes and Vicard, 2009; Busse et al., 2010). The BIT coefficient is statistically very significant and economically relevant: country-pairs with a BIT enjoy approximately 30 percent $(\exp (0.26097)=1.29)$ more FDI flows than country-pairs without one. Other coefficients of the estimated equations are in line with the predicted values of the gravity equation: income, physical proximity, cultural affinities, and common institutions (money) exert a positive force on FDI flows; distance instead is a deterrent. Host-country openness, home-country orientation and membership in the same RTA are statistically insignificant.

[Insert Table 2 about here]

The rest of the table explores the central issue of this paper, namely the optimality of the stock of BITs. To this end, we use three functional forms of NBIT: a linear-fit in column two, a quadratic-fit in column three, and a cubic-fit in column four. As indicated above, we distinguish between country-pairs with bilateral BITs from country-pairs that do not have them. For BIT country-pairs, the linear form of NBIT suggests that other BITs, not only contribute directly to FDI flows, but enhance the effect of bilateral BITs. ${ }^{6}$ Furthermore, a network of BITs exerts a positive influence on FDI flows independently of whether the country-pair has signed a bilateral BIT: in fact, the orders of magnitude of the other BIT coefficient for BIT pairs and non-BIT pairs are comparable. The inference is that both horizontal and vertical integration benefit from BITs. A MNE located in a home country with a large network of BITs may invest in a host country to maximize the benefits of the home country's BIT network (horizontal integration). A MNE located in a home country without a large network of BITs may invest in BIT-rich host country

\footnotetext{
${ }^{6}$ The direct effect of other BITs is approximately one percent; the indirect one is 16 percent, that is the difference of the BIT impact in column two minus that of column one.
} 
to expand sourcing and production facilities (vertical integration). Finally, a MNE may reap potentially the benefits of both horizontal and vertical integration if both countries in the pair have bilateral treaties in addition to their own BIT network. Column three of the table indicates that the coefficients of the quadratic terms of the three NBIT variables are negative and very statistically significant: incremental benefits of additional BIT are positive but declining. Figure 1 draws the total impact of BITs on bilateral FDI flows for BIT country-pairs, home-country non-BIT pairs and host-country non-BIT pairs. The resulting pattern resembles an inverted-U shaped curve, especially for non-BIT pairs. The gentle downward curvature of the BIT- pair curve reflects the strong impact of bilateral treaties on FDI flows and suggests that NBIT can still grow before their effects peak. For non-BIT pairs, the story is different and "peaking" seems to have occurred with NBIT between 80 and 100. The cubic terms of NBIT in column four are either statistically insignificant or zero at the fifth decimal. Therefore, we take the estimate from the quadratic form to be our benchmark specification.

[Insert Figure 1 about here]

\subsection{Tests of robustness}

The robustness of our findings is checked in a variety of ways; results are shown in Table 3. First, column one of this table controls for multilateral resistance factors by employing country-pair FE instead of country-pair RE (as in Table 2, year and country FE are also added). A necessary byproduct of this specification is that time-invariant variables, such as geographic distance, common border, common language, colonial relation and common currency, become perfectly collinear with country-pair FE and are dropped from the estimation. The coefficients of the timevarying variables are in line with those of column three of Table 2. Second, following Frankel 
(1997), we lag by one year potentially endogenous variables such as BIT, GDP, population, currency union, regional trade agreement, FDI openness, and FDI orientation. Again, the results, shown in column two, are very consistent with those of our benchmark specification. In the three remaining columns of the table we address the zero-flow problem with three different methods: first by replacing $\ln (\mathrm{FDI})$ with $\ln (1+\mathrm{FDI})$, then with a zero-inflated Poisson pseudo maximum likelihood estimator, or PPML, and finally with a zero inflated negative binomial maximum likelihood, or NBPML.

The simple method of adding one to the dependent variable is frequently employed in “treating zeros" (Neumayer and Spess, 2005; Santos Silva and Tenreyro, 2006; Bénassy-Quéré et al., 2007). The sample size naturally expands, in our case to 32,574 observations. The estimates in column three of Table 3 show that the total effect of NBIT on FDI flows is strictly positive for BIT pairs: the quadratic term of NBIT is negative but statistically insignificant. For non-BIT pairs, the total effect of NBIT is positive but decreasing in scale.

The addition of a large number of zero values to FDI flows might bias OLS results if the error term in (1) is heteroskedastic. Santos Silva and Tenreyro (2006), Burger et al. (2009), Desborders and Vicard (2009) and Busse et al. (2010) propose the use of Poisson type non-linear regression models. Column four of the table displays the results from a PPML estimation (Santos Silva and Tenreyro, 2006) and column five those from a NBPML estimation (Burger et al., 2009). In both cases, for BIT pairs the total effect of NBIT on FDI flows is positive but decreasing in scale. For non-BIT pairs, the impact of NBIT is mixed: positive but decreasing in scale for the home country and statistically insignificant for the host country.

In sum, our robustness checks confirm the main message of our benchmark equation: NBIT is subject to diminishing returns and its effects on FDI flows peaks. 
[Insert Table 3 about here]

\section{BIT Network Diversity as a Limiting Factor}

In this section, we explore what may be the limiting factor underlying the inverted U-curve of Figure 1. We start with the observation that economic differences within country-pairs have declined substantially over time, in contrast to what has happened to non-BIT pairs (Elkins et al., 2006). The fact that the economic structures of new BIT partners are converging suggests that bilateral investment treaties target similar countries in preference of dissimilar countries. This pattern is consistent with investments made by horizontally integrated MNEs. But, for vertically integrated MNEs country similarities are bound to reduce incentives to sign such agreements (Elkins et al., 2006). The natural question is whether BIT network diversity is the scarce input placing an upper limit to the marginal returns of NBIT. The answer to the question is that much will depend on the mix of horizontally and vertically integrated MNEs.

The case for corporate diversification, in products and markets, is no different than portfolio diversification (Rugman, 1979; Errunza and Senbet, 1981): spread the risk among various activities that are less than perfectly correlated. At relatively low levels of initial diversification, a MNE may prefer to invest in a more than a less diversified economy. A country's BIT network diversity reflects those preferences. While some MNEs may focus primarily on domestic markets, diversifying MNEs will prefer to invest in countries with a high degree of diversity in their BIT network. This diversity is captured in our data by the entropy index (2), originally developed as a measure of product diversification. ${ }^{7}$ Our network diversity is made to interact with bilateral BITs, pair's other BITs, home and home and host country NBITs.

\footnotetext{
${ }^{7}$ Shannon and Weaver (1949) were the first to propose the entropy measure, which was then employed by Coleman (1964) in network analysis. The cited Jacquemin and Berry (1979) analyzed in more depth the properties of the diversification index.
} 
The estimation of this specification is shown in Table 4.

[Insert Table 4 about here]

Network diversity interacts positively and in a statistical significant manner with bilateral investment treaties; see column one of Table 4. BIT network diversity is attractive to foreign investors. On the other hand, the coefficient of BIT variable turns out to be insignificant, meaning that not all BITs increase FDI flows and the effect of BIT depends on the country and country pair's BIT network characteristics. In Column two, we add an interaction term between the pair's other NBIT and the pair's network diversity index instead of the quadratic term of the BIT pair's NBIT. The interaction term is negative, albeit at the 10 percent level. In Column three, two other interaction terms were added: diversity interacts with the home country's NBIT and with the host country's NBIT. Of the three interaction terms, two are significantly negative. The overall inference from the table is that network diversity plays a role in FDI flows. The interaction of diversity with different measures of NBIT mimics (or provides a justification) to some extent the quadratic term of Table 2. As the numbers of countries in the network expands, FDI flows rise but at a diminishing rate. Figure 2 portrays an inverted U-curve in FDI flow/NBIT space computed from column three of Table 4. The inversion of the U-curve is more delineated than those shown in Figure 1. NBIT peaks between 40 and 60; zero FDI flow value is reached when NBIT is about 145; after that it falls into negative territory.

In sum, the diversity tests, while corroborating the findings of Table 2, give us a plausible story underlying the diminishing returns of NBIT on FDI flows: BIT network diversity may its limiting force.

[Insert Figure 2 about here] 


\section{Conclusions}

Our main finding is that the stock of BITs is subject to diminishing returns measured in terms of FDI flows. Diminishing returns are more pronounced among country-pairs that have not signed bilateral BITs but have their own BIT network than among country-pairs with their own bilateral BITs. The result that for a given country's BIT network, a MNE finds more value in investing where a bilateral treaty is in place may suggest either stronger property-rights protection or greater latitude to use the host country as an export platform. Our subsidiary finding is that an index of a country's BIT network diversity mimics approximately the inverted U curve underlying our main finding. We use this result as a plausible explanation of the limiting force underlying the diminishing returns of the stock of BITs in a world where there is a mix between horizontally and vertically integrated MNEs.

Our paper has also the important policy implication that decision makers in government, before signing a bilateral BIT, must analyze, not only the two countries' economic, geographic, and institutional characteristics, but also the characteristics of their own BIT network and the networks of all its trading partners. Otherwise, one runs the risk of signing a costly investment treaty without any reasonable assurance of obtaining a positive payoff.

Finally, this paper has keyed on the economic diversity of a country's BIT network as a limiting force on the effect of BITs on FDI. Future research may want to inquire on other network characteristics, such as how they impact MNE strategies concerning horizontal and vertical integration and the length and complexity of international supply chains. 


\section{References}

Anderson, James E., van Wincoop, Eric, 2003. Gravity with gravitas: A solution to the border problem. American Economic Review 93, 1,170-192.

Andriamananjara, Soamiely, 1999. On the size and number of regional integration arrangements: A political economy model. World Bank Policy Research Working Paper No. 2117. Washington, D.C.

Bhagwati, Jagdish, 1991. The World Trading System at Risk. Princeton University Press, Princeton, NJ.

Baier, Scott L., Bergstrand, Jeffrey H, 2007. Do free trade agreements actually increase members' international trade? Journal of International Economics 71, 1, 72-95.

Baldwin, Richard, Taglioni, Daria, 2007. Trade effects of the euro: A comparison of estimators. Journal of Economic Integration 22, 4, 780-818.

Bénassy-Quéré, Agnès, Coupet, Maylis, Mayer, Thierry, 2007. Institutional determinants of foreign direct investment. The World Economy 30, 5, 764-782.

Burger, Martijn J., Van Oort, Frank, Linders, Gert-Jan M, 2009. On the specification of the gravity model of trade: Zeros, excess zeros, and zero-inflated estimation. Spatial Economic Analysis 4, 2, 167-190.

Busse, Matthias, Königer, Jens, Nunnenkamp, Peter, 2010. FDI promotion through bilateral investment treaties: More than a bit? Review of World Economics 146, 1, 147-177.

Carrère, Celine, 2006. Revisiting the effects of regional trade agreements on trade flows with proper specification of the gravity model. European Economics Review 50, 2, 223-247.

Central Intelligence Agency (CIA), 2009. World Factbook. Available at https://www.cia.gov/library/publications/the-world-factbook/index.html. CIA, Washington, D.C.

Colesman, James S., 1964. Introduction to Mathematical Sociology. The Free Press of Glencoe, Collier-Macmillan Limited: London.

Desbordes, Rodolphe, Vicard, Vincent, 2009. Foreign direct investment and bilateral investment treaties: An international political perspective. Journal of Comparative Economics 37, 3, 372-386.

Egger, Peter H., Merlo, Valeria, 2007. The impact of bilateral investment treaties on FDI dynamics. The World Economy 30, 10, 1536-1549.

Egger, Peter H., Pfaffermayr, Michael, 2004. The impact of bilateral investment treaties on foreign direct investment. Journal of Comparative Economics 32, 4, 788-804. 
Ethier, Wilfred J., 2001. Regional Regionalism. In: Lahiri, Sajal (Ed.), Regionalism and Globalization: Theory and Practice. Routledge/New York, pp. 3-15.

Elkins, Zachary, Guzman, Andrew T., Simmons, Beth A., 2006. Competing for capital: The diffusion of bilateral investment treaties, 1960-2000. International Organization 60, 4, 811-846.

Errunza, Vihang R., Senbet, Lemma W., 1981. The effects of international operations on the market value of the firm: Theory and evidence. Journal of Finance 36, 2, 401-417.

Frankel, Jeffrey A., 1997. Regional Trading Blocs in the World Economic System. Institute of International Economics, Washington, D.C.

Fratianni, Michele U., 2009. The gravity equation in international trade. In: Rugman, Alan M. (Ed.), The Oxford Handbook of International Business, Oxford University Press/New York, pp.72-89.

Fratianni, Michele U., Marchionne, Francesco, Oh, Chang H., 2010. The Gravity equation in international business research: Theory and practice. Working Paper, 2010.

Fratianni, Michele U., Oh, Chang H., 2009. Expanding RTAs, trade flows and the multinational enterprise. Journal of International Business Studies 40, 7, 1206-1227.

Fratianni, Michele U., Pattison, John, 2001. International organisation in a world of regional trade agreements: Lessons from club theory. The World Economy 24, 3, 333-358.

Guiso, Luigi, Sapienza, Paola, Zingales, Luigi, 2009. Cultural biases in economic exchange? Quarterly Journal of Economics 124, 3, 1095-1131.

Guzman, Andrew T., 1998. Why LDCs sign treaties that hurt them: Explaining the popularity of bilateral investment treaties. Virginia Journal of International Law, 38, 639-688.

Hallward-Dreimeier, Mary, 2003. Do bilateral investment treaties attract foreign direct investment? Only a bit... and they could bite. World Bank Working Paper No.3121. Washington, D.C.

Head, Keith, Ries, John, 2008. FDI as an outcome of market for corporate control: Theory and evidence. Journal of International Economics 74, 1, 2-20.

Helpman, Elhanan, 1984. A simple theory of international trade with multinational corporations. Journal of Political Economy 92, 3, 451-472.

Hoekman, Bernard, Saggi, Kamal, 2000. Mutilateral disciplines for investment-related policies? In: Guerrieri, Paolo, Scharrer, Hans-Eckart (Eds.), Global Governance, Regionalism, and the International Economy. Nomos Verlagsgesellschaft, Baden-Baden.

Jacquemin, Alexis P., Berry, Charles H., 1979. Entropy measure of diversification and corporate 
growth. Journal of Industrial Economics 27, 4, 359-369.

King, Gary, 1988. Statistical models for political science event counts: bias in conventional procedures and evidence for the exponential Poisson regression model. American Journal of Political Science, 32, 838-863.

Krugman, Paul, 1991. Is bilateralism bad? In: Helpman, Elhanan, Razin, Assaf (Eds.), International Trade and Trade Policy. MIT Press/ Cambridge, MA, pp. 9-23.

Markusen, James R., 1984. Multinationals, multi-plant economies, and the gains from trade. Journal of International Economics 16, 3/4, 205-226.

Markusen, James R., Maskus, Keith E., 2002. Discriminating among alterative theories of the multinational enterprise. Review of International Economics 10, 4, 694-707.

Neary, J. Peter, 2009. Trade costs and foreign direct investment. International Review of Economics and Finance 18, 2, 207-218.

Neumayer, Eric, Spess, Laura, 2005. Do bilateral investment treaties increase foreign direct investment to developing countries? World Development 33, 10, 1567-1585.

Rugman, Alan M., 1979. International Diversification and the Multinational Enterprise. Lexington Books, Lexington, MA.

Salacuse, Jeswald W., Sullivan, Nicholas P, 2005. Do BITs really work? An evaluation of bilateral investment treaties and their grand bargain. Harvard International Law Journal 46, 1, $67-130$.

Santos Silva, Joao M.C., Tenreyro, Silvana, 2006. The log of gravity. Review of Economics and Statistics 88, 4, 641-658.

Shannon, Claude E., Weaver, W., 1949. The Mathematical Theory of Communication. University of Illinois Press, Chicago, IL. (Paperback edition, 1963).

Sornarajah, M., 1986. State responsibility and bilateral investment treaties. Journal of World Trade Law 20, 79-98.

United Nations Conference on Trade and Development (UNCTAD), 2000. Bilateral investment treaties. United Nations, New York.

UNCTAD, 2008. International investment rule-making: Stocktaking, Challenges, and the way forward. UNCTAD Series on Investment Policies for Development. United Nations, New York.

UNCTAD, 2010. Bilateral Investment Treaties. Available at http://www.unctadxi.org/templates/docsearch 779.aspx. United Nations, New York. 
Vandevelde, Kenneth J., 1998. The political economy of a bilateral investment treaty. American Journal of International Law, 92, 4, 621-641

Viner, Jacob, 1950. The customs union issue. Carnegie Endowment for International Peace, New York.

Wheeler, David, Mody, Ashoka, 1992. International investment location decisions: The case of U.S. firms. Journal of International Economics, 33,1/2, 57-76.

World Bank, 2009. World Development Indicator. Available at http://info.worldbank.org/wdi. The World Bank, Washington, D.C.

Yi, Sang-S., 1996. Endogenous formation of customs unions under imperfect competition: open regionalism is good. Journal of International Economics, 41, 1/2, 153-177. 
TABLE 1 Data Description

\begin{tabular}{|c|c|c|}
\hline Variable & Description & Source \\
\hline Inward FDI & Log of nominal inward FDI flows in millions US dollars. & $\operatorname{OECD}(2008)^{\mathrm{a}}$ \\
\hline $\begin{array}{l}\text { Bilateral Investment Treaty } \\
\text { (BIT) }\end{array}$ & $\begin{array}{l}\text { If two countries have bilateral investment treaty in the } \\
\text { observation year, BIT }=1 \text {; Otherwise } 0 \text {. }\end{array}$ & United Nation $^{\mathrm{b}}$ \\
\hline Pair's Other BITs & $\begin{array}{l}\text { Number of home and host countries' other BITs when the } \\
\text { pair has a BIT in the observation year. }\end{array}$ & United Nation \\
\hline $\begin{array}{l}\text { Number of Host (Home) } \\
\text { Country BITs }\end{array}$ & $\begin{array}{l}\text { The number of host (home) country's BITs when the pair } \\
\text { does not has a BIT in the observation year. }\end{array}$ & United Nation \\
\hline $\begin{array}{l}\ln (\text { Host Country Nominal } \\
\text { GDP) }\end{array}$ & Log of host country's nominal GDP in US dollars. & World Bank ${ }^{\mathrm{c}}$ \\
\hline $\begin{array}{l}\ln (\text { Home Country Nominal } \\
\text { GDP) }\end{array}$ & Log of home country's nominal GDP in US dollars. & World Bank \\
\hline $\begin{array}{l}\ln (\text { Host Country } \\
\text { Population })\end{array}$ & Log of host country's nominal GDP in US dollars. & World Bank \\
\hline $\begin{array}{l}\ln (\text { Home Country } \\
\text { Population) }\end{array}$ & Log of home country's nominal GDP in US dollars. & World Bank \\
\hline $\begin{array}{l}\text { Host Country FDI } \\
\text { Openness }\end{array}$ & Host country's inward FDI as a percent of GDP & World Bank \\
\hline $\begin{array}{l}\text { Home Country FDI } \\
\text { Orientation }\end{array}$ & Home country's outward FDI as a percent of GDP & World Bank \\
\hline $\ln ($ Distance $)$ & $\begin{array}{l}\text { Log of geographic distance (in miles) between two } \\
\text { countries in a pair }\end{array}$ & $\begin{array}{l}\text { Fratianni and } \\
\text { Oh (2009) }\end{array}$ \\
\hline Common Border & $\begin{array}{l}\text { If two countries share a common border, Border }=1 \\
\text { otherwise } 0 \text {. }\end{array}$ & CIA $^{\mathrm{d}}$ \\
\hline Common Language & $\begin{array}{l}\text { If two countries share same official language(s), Common } \\
\text { Language }=1 ; \text { otherwise } 0 .\end{array}$ & CIA \\
\hline Colonial Relationship & $\begin{array}{l}\text { If two countries were involved in a colonial relationship } \\
\text { after } 1945 \text {, Colonial Relationship = } 1 \text {; otherwise } 0 \text {. }\end{array}$ & CIA \\
\hline Currency Union & $\begin{array}{l}\text { If two countries share the same currency or a unit exchange } \\
\text { rate, Currency Union }=1 \text {; otherwise } 0 \text {. }\end{array}$ & $\operatorname{IMF}^{\mathrm{e}}$ \\
\hline $\begin{array}{l}\text { Regional Trade Agreements } \\
\text { (RTA) }\end{array}$ & $\begin{array}{l}\text { If two countries belong to the same major RTA in the } \\
\text { observation year, RTA }=1 \text {; otherwise } 0 \text {. }\end{array}$ & $\mathrm{WTO}^{\mathrm{f}}$ \\
\hline Network Diversity & $\begin{array}{l}\text { Entropy measure (Jacquemin and Berry, 1979) of diversity } \\
\text { using a share of GDP in a BIT network. Calculated for BIT } \\
\text { pairs, non-BIT pairs (home and host counties). }\end{array}$ & $\begin{array}{l}\text { Authors' } \\
\text { calculation }\end{array}$ \\
\hline
\end{tabular}

Note: " "International Direct Investment Statistics 2008 on CD-Rom", Organisation for Economic Co-operation and Development (OECD, 2008).

${ }^{\mathrm{b}}$ United Nations Conference on Trade and Development (UNCTAD):

http://www.unctad.org/Templates/Page.asp?intItemID=2344\&lang=1 (last accessed on 2009.3.25).

c "World Development Indicators", World Bank:

http://ddp-ext.worldbank.org/ext/DDPQQ/member.do?method=getMembers\&userid=1\&queryId=6 (last accessed on 2009.11.16).

d "World Factbook", Central Intelligence Agency (CIA): https://www.cia.gov/library/publications/the-worldfactbook/index.html (last accessed on 2009.11.16).

"The basic source for currency unions is the IMF's "Schedule of Par Values" and issues of the IMF's

"Annual Report on Exchange Rate Arrangements and Exchange Restrictions".

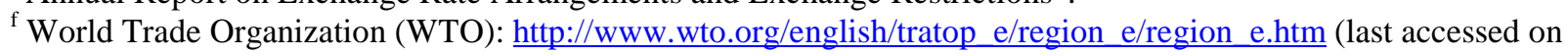
2009.11.16). 
TABLE 2 FDI Flows and Optimal Number of Bilateral Investment Treaties

\begin{tabular}{|c|c|c|c|c|}
\hline & (1) & (2) & (3) & (4) \\
\hline Bilateral Investment Treaty (BIT) & $\begin{array}{r}0.26097 * * * \\
(0.04131)\end{array}$ & $\begin{array}{r}0.37859 * * * \\
(0.06620)\end{array}$ & $\begin{array}{r}0.33306 * * \\
(0.10247)\end{array}$ & $\begin{array}{r}0.19062 \\
(0.15329)\end{array}$ \\
\hline \multicolumn{5}{|l|}{ BIT Pairs } \\
\hline Pair's Other BITs & & $\begin{array}{r}0.00707 * * * \\
(0.00111)\end{array}$ & $\begin{array}{r}0.01689 * * * \\
(0.00266)\end{array}$ & $\begin{array}{c}0.01686^{*} \\
(0.00660)\end{array}$ \\
\hline Pair's Other BITs Squared & & & $\begin{array}{r}-0.00005 * * \\
(0.00001)\end{array}$ & $\begin{array}{l}(0.00007) \\
(0.00009)\end{array}$ \\
\hline Pair's Other BITs Cubic & & & & $\begin{array}{r}0.00000 \\
(0.00000)\end{array}$ \\
\hline \multicolumn{5}{|l|}{ Non-BIT Pairs } \\
\hline Number of Host Country BITs & & $\begin{array}{r}0.00902 * * * \\
(0.00125)\end{array}$ & $\begin{array}{r}0.01841 * * * \\
(0.00236)\end{array}$ & $\begin{array}{r}0.00413 \\
(0.00412)\end{array}$ \\
\hline Number of Host Country BITs Squared & & & $\begin{array}{r}-0.00009 * * * \\
(0.00002)\end{array}$ & $\begin{array}{r}0.00032 * * \\
(0.00010)\end{array}$ \\
\hline Number of Host Country BITs Cubic & & & & $\begin{array}{r}-0.00000 * * * * \\
(0.00000)\end{array}$ \\
\hline Number of Home Country BITs & & $\begin{array}{r}0.01021^{* * *} * \\
(0.00124)\end{array}$ & $\begin{array}{r}0.02433 * * * \\
(0.00232)\end{array}$ & $\begin{array}{r}0.01106^{* *} \\
(0.00408)\end{array}$ \\
\hline Number of Home Country BITs Squared & & & $\begin{array}{r}-0.00014 * * * \\
(0.00002)\end{array}$ & $\begin{array}{c}0.00023^{*} \\
(0.00010)\end{array}$ \\
\hline Number of Home Country BITs Cubic & & & & $\begin{array}{r}-0.00000 * * * \\
(0.00000)\end{array}$ \\
\hline \multicolumn{5}{|l|}{ Control Variables } \\
\hline $\ln$ (Destination Country Nominal GDP) & $\begin{array}{r}0.67431 * * * \\
(0.05151)\end{array}$ & $\begin{array}{r}0.69227 * * * \\
(0.05137)\end{array}$ & $\begin{array}{r}0.69023 * * * \\
(0.05127)\end{array}$ & $\begin{array}{r}0.68640 * * * \\
(0.05124)\end{array}$ \\
\hline $\ln ($ Source Country Nominal GDP) & $\begin{array}{r}0.76054 * * * \\
(0.06269)\end{array}$ & $\begin{array}{r}0.78102 * * * \\
(0.06247)\end{array}$ & $\begin{array}{r}0.76717 * * * \\
(0.06233)\end{array}$ & $\begin{array}{r}0.75182 * * * \\
(0.06255)\end{array}$ \\
\hline $\ln$ (Destination Country Population) & $\begin{array}{r}-2.28781 * * * \\
(0.19633)\end{array}$ & $\begin{array}{r}-1.87068 * * * \\
(0.20571)\end{array}$ & $\begin{array}{r}-1.77541 * * * \\
(0.20850)\end{array}$ & $\begin{array}{r}-1.81258 * * * * \\
(0.20847)\end{array}$ \\
\hline $\ln$ (Source Country Population) & $\begin{array}{r}-2.32989 * * * \\
(0.24930)\end{array}$ & $\begin{array}{r}-1.86662 * * * \\
(0.25687)\end{array}$ & $\begin{array}{r}-1.94372 * * * * \\
(0.25940)\end{array}$ & $\begin{array}{r}-1.97828 * * * \\
(0.26035)\end{array}$ \\
\hline Host Country FDI Openness & $\begin{array}{r}0.00013 \\
(0.00087)\end{array}$ & $\begin{array}{r}0.00042 \\
(0.00087)\end{array}$ & $\begin{array}{r}0.00053 \\
(0.00087)\end{array}$ & $\begin{array}{r}0.00060 \\
(0.00087)\end{array}$ \\
\hline Home Country FDI Orientation & $\begin{array}{r}0.00023 \\
(0.00074)\end{array}$ & $\begin{array}{r}0.00044 \\
(0.00075)\end{array}$ & $\begin{array}{r}0.00050 \\
(0.00074)\end{array}$ & $\begin{array}{r}0.00055 \\
(0.00075)\end{array}$ \\
\hline $\ln ($ Distance $)$ & $\begin{array}{r}-1.13919 * * * \\
(0.06590)\end{array}$ & $\begin{array}{r}-1.13743 * * * \\
(0.06585)\end{array}$ & $\begin{array}{r}-1.15166 * * * \\
(0.06589)\end{array}$ & $\begin{array}{r}-1.15452 * * * * \\
(0.06582)\end{array}$ \\
\hline Common Border & $\begin{array}{r}0.28634 \\
(0.20421)\end{array}$ & $\begin{array}{r}0.28042 \\
(0.20627)\end{array}$ & $\begin{array}{r}0.27292 \\
(0.20568)\end{array}$ & $\begin{array}{r}0.27130 \\
(0.20516)\end{array}$ \\
\hline Common Language & $\begin{array}{c}0.27965 \dagger \\
(0.16610)\end{array}$ & $\begin{array}{r}0.26823 \\
(0.16657)\end{array}$ & $\begin{array}{c}0.27431 \dagger \\
(0.16642)\end{array}$ & $\begin{array}{c}0.28277 \dagger \\
(0.16604)\end{array}$ \\
\hline Colonial Relation & $\begin{array}{r}1.16777 * * * \\
(0.19292)\end{array}$ & $\begin{array}{r}1.17507 * * * \\
(0.19389)\end{array}$ & $\begin{array}{r}1.17552 * * * \\
(0.19390)\end{array}$ & $\begin{array}{r}1.17249 * * * \\
(0.19313)\end{array}$ \\
\hline Currency Union & $\begin{array}{r}0.30762 * * * \\
(0.06805)\end{array}$ & $\begin{array}{r}0.19218 * * \\
(0.07085)\end{array}$ & $\begin{array}{c}0.17844^{*} \\
(0.06992)\end{array}$ & $\begin{array}{c}0.16203^{*} \\
(0.06956)\end{array}$ \\
\hline Regional Trade Agreement (RTA) & $\begin{array}{r}0.04440 \\
(0.05515) \\
\end{array}$ & $\begin{array}{r}0.05099 \\
(0.05527) \\
\end{array}$ & $\begin{array}{r}0.00997 \\
(0.05535) \\
\end{array}$ & $\begin{array}{r}0.01935 \\
(0.05533) \\
\end{array}$ \\
\hline R-Squared & 0.6348 & 0.6354 & 0.6355 & 0.6366 \\
\hline
\end{tabular}

Note: $\mathrm{N}=21,099 . \dagger$ if $\mathrm{p}<0.10, *$ if $\mathrm{p}<0.05 ; * *$ if $\mathrm{p}<0.01 ; * * *$ if $\mathrm{p}<0.001$. Constant, country-fixed effects, yearfixed effects, and country-pair random effects are estimated but not reported here. 
TABLE 3 Robustness Check

\begin{tabular}{|c|c|c|c|c|c|}
\hline & \multirow{2}{*}{$\begin{array}{r}\text { Country-pair } \\
\text { Fixed Effects } \\
(1)\end{array}$} & \multirow{2}{*}{$\begin{array}{r}\text { Lagged } \\
\text { Variables } 1) \\
(2)\end{array}$} & \multicolumn{3}{|c|}{ Control for Zero Flows } \\
\hline & & & $\begin{array}{r}\ln (1+\mathrm{FDI}) \\
(3)\end{array}$ & $\begin{array}{r}\text { PPML }^{2)} \\
\text { (4) }\end{array}$ & $\begin{array}{r}\mathrm{NBPML}^{3)} \\
(5)\end{array}$ \\
\hline Bilateral Investment Treaty (BIT) & $0.27366^{*}$ & $0.25456 * * *$ & $0.19157^{*}$ & $0.32521 *$ & $0.32611 \dagger$ \\
\hline Pair's Other BITs & $\begin{array}{r}0.01799 * * * \\
(0.00279)\end{array}$ & $\begin{array}{r}0.01833 * * * \\
(0.00224)\end{array}$ & $\begin{array}{r}0.00761 * * \\
(0.00227)\end{array}$ & $\begin{array}{r}0.01618 * * * \\
(0.00454)\end{array}$ & $\begin{array}{r}0.01620 * * * \\
(0.00457)\end{array}$ \\
\hline Pair's Other BITs Squared & $\begin{array}{r}-0.00005^{* *} \\
(0.00002)\end{array}$ & $\begin{array}{r}-0.00006 * * * \\
(0.00001)\end{array}$ & $\begin{array}{r}-0.00000 \\
(0.00001)\end{array}$ & $\begin{array}{r}-0.00009 * * * * \\
(0.00026)\end{array}$ & $\begin{array}{r}-0.00009 * * \\
(0.00026)\end{array}$ \\
\hline Number of Host Country BITs & $\begin{array}{r}0.01877 * * * \\
(0.002416)\end{array}$ & $\begin{array}{r}0.01727 * * * \\
(0.00240)\end{array}$ & $\begin{array}{r}0.01239 * * * \\
(0.00177)\end{array}$ & $\begin{array}{r}0.00103 \\
(0.00378)\end{array}$ & $\begin{array}{r}0.00097 \\
(0.00388)\end{array}$ \\
\hline Number of Host Country BITs Squared & $\begin{array}{r}-0.00009 * * * \\
(0.00002)\end{array}$ & $\begin{array}{r}-0.00007 * * * \\
(0.00002)\end{array}$ & $\begin{array}{r}-0.00005^{* *} \\
(0.00002)\end{array}$ & $\begin{array}{r}0.00000 \\
(0.00004)\end{array}$ & $\begin{array}{r}0.00000 \\
(0.00004)\end{array}$ \\
\hline Number of Home Country BITs & $\begin{array}{r}0.02469 * * * \\
(0.00241)\end{array}$ & $\begin{array}{r}0.02375^{* * *} * \\
(0.00234)\end{array}$ & $\begin{array}{r}0.02213^{* * *} * \\
(0.00168)\end{array}$ & $\begin{array}{r}0.02278 * * * \\
(0.00443)\end{array}$ & $\begin{array}{r}0.02294 * * * * \\
(0.00592)\end{array}$ \\
\hline Number of Home Country BITs Squared & $\begin{array}{r}-0.00014 * * * \\
(0.00002)\end{array}$ & $\begin{array}{r}-0.00014 * * * \\
(0.00002)\end{array}$ & $\begin{array}{r}-0.00015^{* * * *} \\
(0.00002)\end{array}$ & $\begin{array}{r}-0.00018 * * * \\
(0.00003)\end{array}$ & $\begin{array}{r}-0.00018 * * * * \\
(0.00005)\end{array}$ \\
\hline $\ln ($ Host Country Nominal GDP) & $\begin{array}{r}0.71462 * * * \\
(0.05273)\end{array}$ & $\begin{array}{r}0.57281 * * * * \\
(0.05172)\end{array}$ & $\begin{array}{r}0.35212 * * * \\
(0.03221)\end{array}$ & $\begin{array}{r}0.47527 * * * \\
(0.07559)\end{array}$ & $\begin{array}{r}0.47535^{* * *} * \\
(0.08910)\end{array}$ \\
\hline $\ln ($ Home Country Nominal GDP) & $\begin{array}{r}0.78775^{* * *} \\
(0.06406)\end{array}$ & $\begin{array}{r}0.60164 * * * * \\
(0.06393)\end{array}$ & $\begin{array}{r}0.36951 * * * \\
(0.03776)\end{array}$ & $\begin{array}{r}0.57455^{* * *} \\
(0.10749)\end{array}$ & $\begin{array}{r}0.57432 * * * \\
(0.12504)\end{array}$ \\
\hline $\ln ($ Host Country Population) & $\begin{array}{r}-1.75211^{* * *} \\
(0.21867)\end{array}$ & $\begin{array}{r}-1.78331 \text { *** } \\
(0.20765)\end{array}$ & $\begin{array}{r}-1.19947 * * * \\
(0.13227)\end{array}$ & $\begin{array}{r}-2.20033^{* * *} * \\
(0.30040)\end{array}$ & $\begin{array}{r}-2.19870 \\
(1.40928)\end{array}$ \\
\hline $\ln$ (Home Country Population) & $\begin{array}{r}-1.98954 * * * \\
(0.26774)\end{array}$ & $\begin{array}{r}-2.00809 * * * \\
(0.26243)\end{array}$ & $\begin{array}{r}-1.95689^{* * *} * \\
(0.14645)\end{array}$ & $\begin{array}{r}-1.80031 * * * \\
(0.42333)\end{array}$ & $\begin{array}{r}-1.80291 * * \\
(0.56925)\end{array}$ \\
\hline Host Country FDI Openness & $\begin{array}{r}0.00031 \\
(0.00072)\end{array}$ & $\begin{array}{r}0.00131 \\
(0.00081)\end{array}$ & $\begin{array}{r}0.00033 \\
(0.00049)\end{array}$ & $\begin{array}{r}0.00144 \\
(0.00123)\end{array}$ & $\begin{array}{r}0.00140 \\
(0.00124)\end{array}$ \\
\hline Home Country FDI Orientation & $\begin{array}{r}0.00031 \\
(0.00072)\end{array}$ & $\begin{array}{r}0.00131 \\
(0.00081)\end{array}$ & $\begin{array}{r}0.00033 \\
(0.00049)\end{array}$ & $\begin{array}{r}0.00144 \\
(0.00123)\end{array}$ & $\begin{array}{r}0.00140 \\
(0.00124)\end{array}$ \\
\hline $\ln$ (Distance) & NA & $\begin{array}{r}-1.1651^{* * * *} \\
(0.06757)\end{array}$ & $\begin{array}{r}-0.64392 * * * \\
(0.03162)\end{array}$ & $\begin{array}{r}-0.95397 * * * \\
(0.02750)\end{array}$ & $\begin{array}{r}-0.95349 * * * \\
(0.02754)\end{array}$ \\
\hline Common Border & NA & $\begin{array}{r}0.28910 \\
(0.21040)\end{array}$ & $\begin{array}{r}0.61008 * * * \\
(0.12306)\end{array}$ & $\begin{array}{r}0.52350 * * * \\
(0.08793)\end{array}$ & $\begin{array}{r}0.52389 * * * * \\
(0.08817)\end{array}$ \\
\hline Common Language & NA & $\begin{array}{c}0.36248^{*} \\
(0.16959)\end{array}$ & $\begin{array}{c}0.16037 * \\
(0.07592)\end{array}$ & $\begin{array}{r}0.60996^{* * *} \\
(0.07434)\end{array}$ & $\begin{array}{r}0.60734 * * * \\
\quad(0.07443)\end{array}$ \\
\hline Colonial Relation & NA & $\begin{array}{r}1.16718^{* * * *} \\
(0.19548)\end{array}$ & $\begin{array}{r}0.90607 * * * \\
(0.10420)\end{array}$ & $\begin{array}{r}1.76491^{* * * *} \\
(0.08830)\end{array}$ & $\begin{array}{r}1.76626^{* * * *} \\
(0.08874)\end{array}$ \\
\hline Currency Union & NA & $\begin{array}{r}0.20762 * * \\
(0.07249)\end{array}$ & $\begin{array}{r}0.45664 * * * * \\
(0.06916)\end{array}$ & $\begin{array}{r}0.10742 \\
(0.11568)\end{array}$ & $\begin{array}{r}0.10658 \\
(0.11864)\end{array}$ \\
\hline Regional Trade Agreement (RTA) & $\begin{array}{r}-0.01443 \\
(0.05835) \\
\end{array}$ & $\begin{array}{r}0.05049 \\
(0.06011) \\
\end{array}$ & $\begin{array}{r}0.48646 * * * \\
(0.04663)\end{array}$ & $\begin{array}{r}0.23360 * * * \\
(0.06571)\end{array}$ & $\begin{array}{r}0.23357 * * \\
(0.06989) \\
\end{array}$ \\
\hline Number of Observations & 21,099 & 20,223 & 32,574 & 32,574 & 32,574 \\
\hline R-Squared & 0.3074 & 0.6346 & 0.7223 & $\begin{array}{r}0.4298 \\
-105046\end{array}$ & $\begin{array}{r}0.4815 \\
-105050\end{array}$ \\
\hline $\begin{array}{l}\text { Log of Pseudo-Likelihood } \\
\log \text { of the estimate of degree of over-dispersion }\end{array}$ & & & & $\begin{array}{r}-105,046 \\
0.98030 * * * \\
(0.00648)\end{array}$ & $\begin{array}{r}-105,050 \\
0.97924 * * * \\
(0.02588)\end{array}$ \\
\hline
\end{tabular}

Note: See Table 2. ${ }^{1)}$ Bilateral investment treaty, GDP, population, currency union, regional trade agreement, FDI openness, and FDI orientation are lagged for one-year; ${ }^{2)}$ PPML stands for zero inflated Poisson pseudo-maximum-likelihood estimator by Santos Silva and Tenreyro (2006); ${ }^{3)}$ NBPML stands for a zero inflated negative binomial pseudo maximum likelihood regression model by Burger, Van Oort, and Linders (2009). 
TABLE 4 Post-hoc Analysis: The Effect of Diversity in Bilateral Investment Networks

\begin{tabular}{|c|c|c|c|}
\hline & (1) & (2) & (3) \\
\hline \multirow[t]{2}{*}{ Bilateral Investment Treaty (BIT) } & 0.10753 & -0.27957 & -0.27594 \\
\hline & $(0.14799)$ & $(0.21152)$ & $(0.21200)$ \\
\hline \multirow[t]{2}{*}{ BIT $\times$ Network Diversity } & $0.07474 *$ & $0.17144 * * *$ & $0.14301 * * *$ \\
\hline & $(0.03737)$ & $(0.03912)$ & $(0.03891)$ \\
\hline \multirow[t]{2}{*}{ Pair's Other BITs (OBITs) } & $0.01231 * * *$ & $0.01453 * * *$ & $0.01199 * *$ \\
\hline & $(0.00359)$ & $(0.00378)$ & $(0.00385)$ \\
\hline Pair's Other BITs Squared & $\begin{array}{r}-0.00003 \dagger \\
(0.00002)\end{array}$ & & \\
\hline \multirow{2}{*}{$\begin{array}{l}\text { Pair's Other BITs } \\
\text { × BIT Pair's Network Diversity }\end{array}$} & & $-0.00117 *$ & $-0.00098^{*}$ \\
\hline & & $(0.00048)$ & $(0.00048)$ \\
\hline \multirow[t]{2}{*}{ Number of Host Country BITs } & $0.01850 * * *$ & $0.01872 * * *$ & $0.00584 \dagger$ \\
\hline & $(0.00236)$ & $(0.00237)$ & $(0.00328)$ \\
\hline \multirow{2}{*}{ Number of Host Country BITs Squared } & $-0.00009^{* * *}$ & $-0.00009 * * *$ & \\
\hline & $(0.00002)$ & $(0.00002)$ & \\
\hline \multirow{2}{*}{$\begin{array}{l}\text { Number of Host Country BITs } \\
\times \text { Host Country's BIT Network Diversity }\end{array}$} & & & 0.0009 \\
\hline & & & $(0.00070)$ \\
\hline \multirow{2}{*}{ Number of Home Country BITs } & $0.02437 * * *$ & $0.02451 * * *$ & $0.02641 * * *$ \\
\hline & $(0.00232)$ & $(0.00233)$ & $(0.00450)$ \\
\hline \multirow[t]{2}{*}{ Number of Home Country BITs Squared } & $-0.00014 * * *$ & $-0.00014 * * *$ & \\
\hline & $(0.00002)$ & $(0.00002)$ & \\
\hline \multirow{2}{*}{$\begin{array}{l}\text { Number of Home Country BITs } \\
\times \text { Home Country's BIT Network Diversity }\end{array}$} & & & $-0.00345 * * *$ \\
\hline & & & $(0.00093)$ \\
\hline \multirow[t]{2}{*}{$\ln ($ Host Country Nominal GDP) } & $0.68533 * * *$ & $0.68755^{* * *}$ & $0.69136 * * *$ \\
\hline & $(0.05137)$ & $(0.05138)$ & $(0.05144)$ \\
\hline \multirow[t]{2}{*}{$\ln$ (Home Country Nominal GDP) } & $0.76664 * * *$ & $0.76849 * * *$ & $0.77848 * * *$ \\
\hline & $(0.06229)$ & $(0.06227)$ & $(0.06237)$ \\
\hline \multirow[t]{2}{*}{$\ln$ (Host Country Population) } & $-1.76796^{* * *}$ & $-1.78367 * * *$ & $-1.82277 * * *$ \\
\hline & $(0.20852)$ & $(0.20868)$ & $(0.20782)$ \\
\hline \multirow[t]{2}{*}{$\ln$ (Home Country Population) } & $-1.93874 * * *$ & $-1.94509 * * *$ & $-2.08946 * * *$ \\
\hline & $(0.25932)$ & $(0.25904)$ & $(0.26176)$ \\
\hline \multirow[t]{2}{*}{ Host Country FDI Openness } & 0.00049 & 0.00045 & 0.00059 \\
\hline & $(0.00087)$ & $(0.00087)$ & $(0.00087)$ \\
\hline \multirow[t]{2}{*}{ Home Country FDI Orientation } & 0.00054 & 0.00051 & 0.00042 \\
\hline & $(0.00075)$ & $(0.00075)$ & $(0.00075)$ \\
\hline \multirow[t]{2}{*}{$\ln ($ Distance $)$} & $-1.15063^{* * *}$ & $-1.15202 * * *$ & $-1.14287 * * *$ \\
\hline & $(0.06584)$ & $(0.06586)$ & $(0.06588)$ \\
\hline \multirow[t]{2}{*}{ Common Border } & 0.2723 & 0.27171 & 0.27846 \\
\hline & $(0.20543)$ & $(0.20545)$ & $(0.20562)$ \\
\hline \multirow[t]{2}{*}{ Common Language } & 0.27336 & $0.27545 \dagger$ & 0.27381 \\
\hline & $(0.16634)$ & $(0.16648)$ & $(0.16660)$ \\
\hline \multirow[t]{2}{*}{ Colonial Relation } & $1.18082 * * *$ & $1.18035^{* * *}$ & $1.17699 * * *$ \\
\hline & $(0.19381)$ & $(0.19400)$ & $(0.19406)$ \\
\hline \multirow[t]{2}{*}{ Currency Union } & $0.17616^{*}$ & $0.17157 *$ & $0.18637 * *$ \\
\hline & $(0.07007)$ & $(0.07017)$ & $(0.07091)$ \\
\hline \multirow[t]{2}{*}{ Regional Trade Agreement (RTA) } & 0.01472 & 0.01522 & 0.04922 \\
\hline & $(0.05516)$ & $(0.05520)$ & $(0.05519)$ \\
\hline R-Squared & 0.6358 & 0.6357 & 0.6355 \\
\hline
\end{tabular}

Note: $\mathrm{N}=21,099$. See Note in Table 2. A per capita GDP based entropy measure is used to measure the diversify of BIT network. 
FIGURE 1 The Optimal Number of Bilateral Investment Treaties

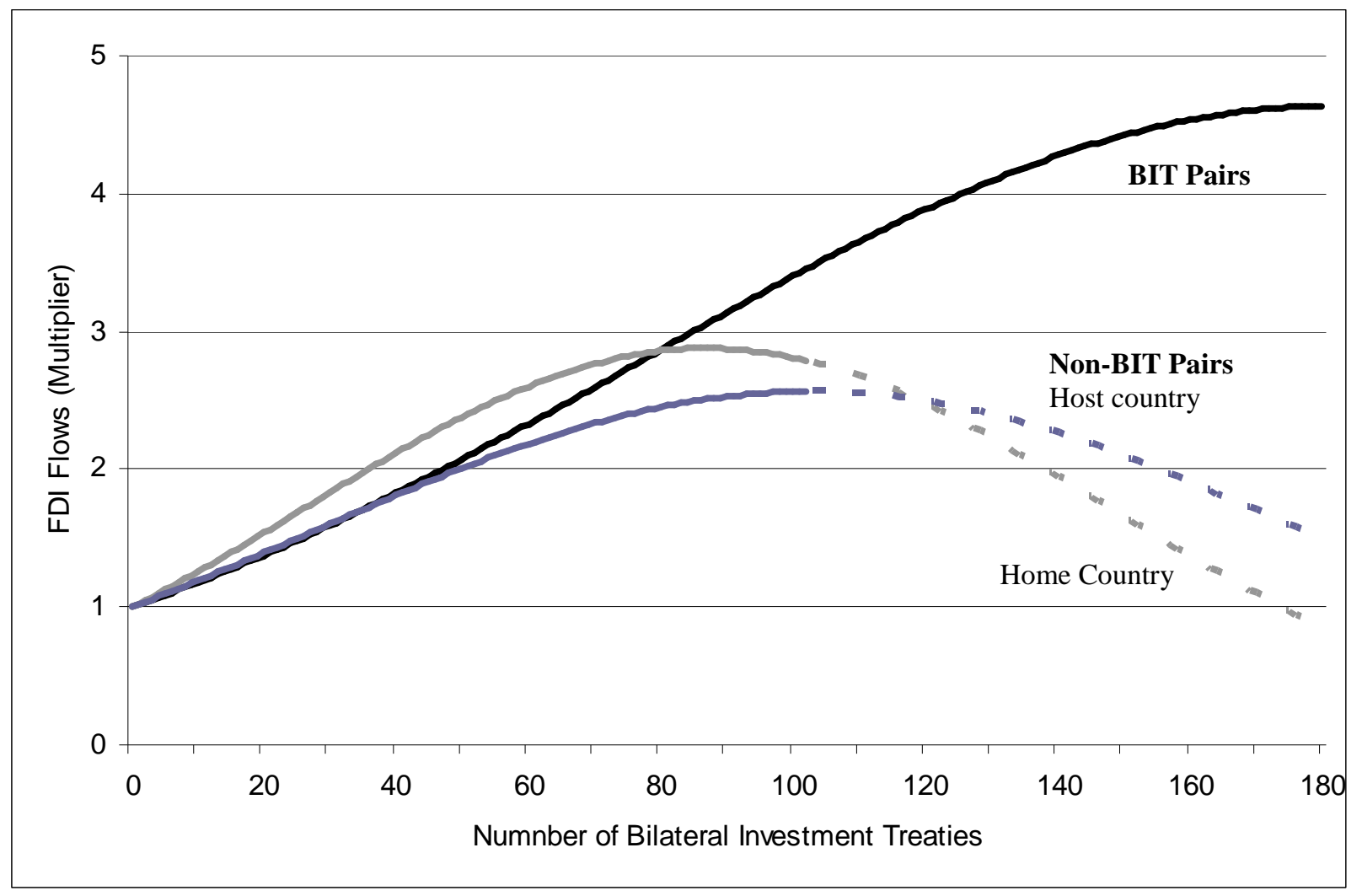


FIGURE 2 The Marginal Effect of BIT Network Diversity on FDI Flows as a Function of the BIT Pair's Number of BITs.

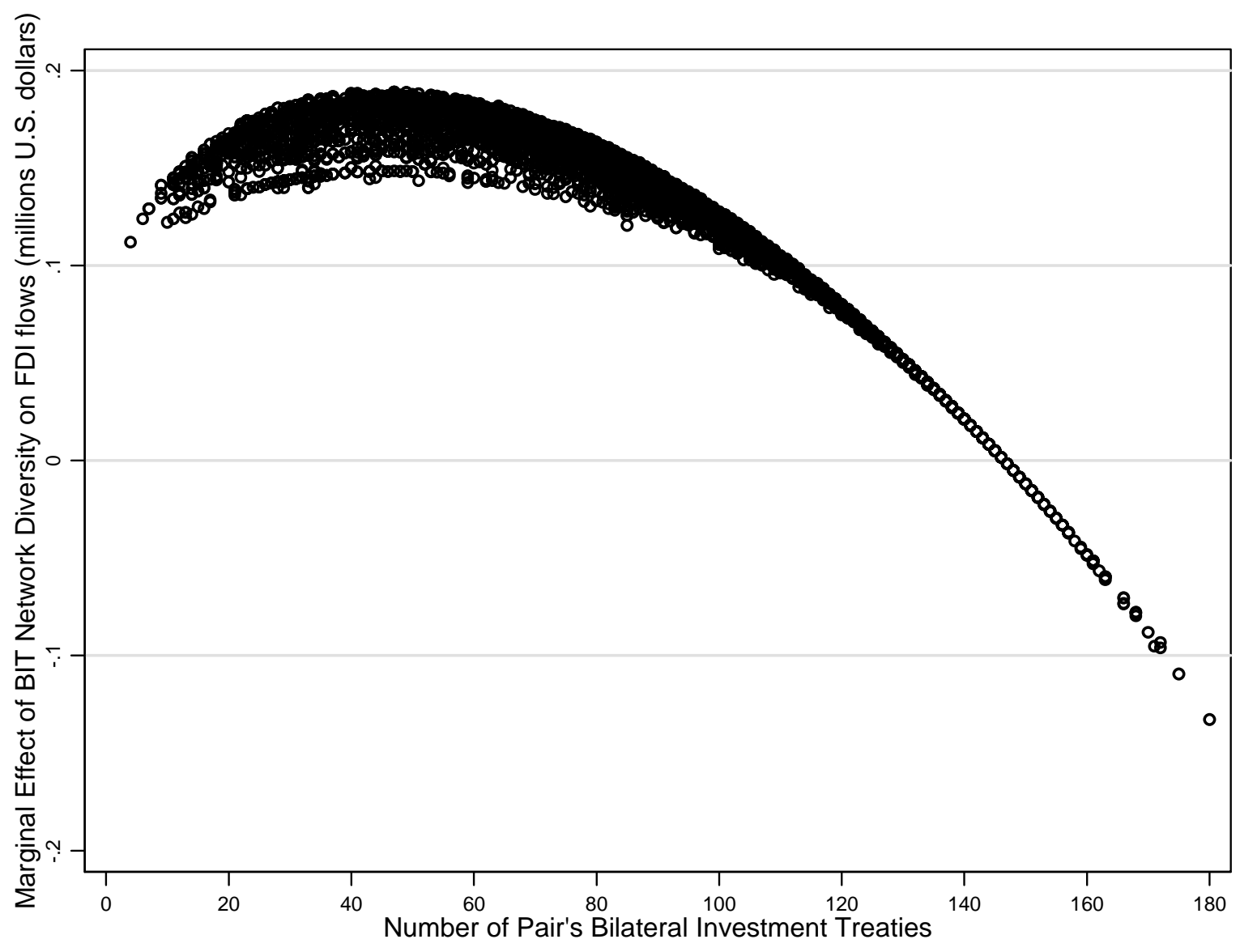


APPENDIX A Descriptive Statistics

\begin{tabular}{lrrrr}
\hline Variable & Mean & Std. Dev. & Min & Max \\
\hline & & & & \\
Outward FDI & 439.107 & $2,385.634$ & 0.00 & $111,412.10$ \\
$\ln ($ Outward FDI) & 3.333 & 2.643 & -7.60 & 11.62 \\
Bilateral Investment Treaty (BIT) & 0.347 & 0.476 & 0 & 1 \\
Pair's Other BITs & 27.565 & 41.981 & 0 & 180 \\
Home Country BITs & 16.138 & 22.844 & 0 & 103 \\
Host Country BITs & 14.143 & 21.224 & 0 & 103 \\
ln(Home Country Nominal GDP) & 26.352 & 1.788 & 18.53 & 30.15 \\
$\ln ($ Host Country Nominal GDP) & 25.951 & 1.917 & 18.53 & 30.15 \\
ln(Home Country Population) & 16.934 & 1.556 & 11.03 & 20.99 \\
ln(Host Country Population) & 16.856 & 1.605 & 11.03 & 20.99 \\
Home Country FDI Orientation & 7.524 & 45.868 & -89.45 & 568.29 \\
Host Country FDI Openness & 6.945 & 38.985 & -33.43 & 522.22 \\
ln(Distance) & 7.683 & 1.081 & 3.56 & 9.41 \\
Common Border & 0.060 & 0.238 & 0 & 1 \\
Common Language & 0.087 & 0.282 & 0 & 1 \\
Colonial Relation & 0.058 & 0.234 & 0 & 1 \\
Currency Union & 0.026 & 0.160 & 0 & 1 \\
Regional Trade Agreement & 0.122 & 0.328 & 0 & 1 \\
BIT Pair's Network Diversity & 2.216 & 3.110 & 0 & 8.8877 \\
Home Country's BIT Network Diversity & 2.690 & 1.342 & 0 & 4.6250 \\
Host Country's BIT Network Diversity & 2.418 & 1.363 & 0 & 4.5850 \\
\hline Note N 21,099. & & & &
\end{tabular}

Note: $\mathrm{N}=21,099$. 
APPENDIX B Country List

\begin{tabular}{|c|c|c|c|}
\hline Albania* & Djibouti $^{*}$ & Kenya & Russia \\
\hline Algeria & Dominica & Korea, Rep. & Saudi Arabia \\
\hline Angola & Dominican Rep. & Kuwait & Senegal \\
\hline Antigua and Barbuda & Ecuador & Lao People's Rep. & Seychelles \\
\hline Argentina & Egypt & Latvia & Sierra Leone \\
\hline Armenia & El Salvador & Lesotho & Singapore \\
\hline Australia & Equatorial Guinea & Liberia & Slovak Rep. \\
\hline Austria & Estonia & Lithuania & Slovenia \\
\hline Azerbaijan & Ethiopia & Luxembourg & Somalia \\
\hline Bahrain & Finland & Macedonia & South Africa \\
\hline Bangladesh & France & Madagascar & Spain \\
\hline Barbados & Gabon & Malawi & Sri Lanka \\
\hline Belarus & Gambia & Malaysia & St. Lucia \\
\hline Belgium & Georgia & Mali & St. Vincent \& Grenadines \\
\hline Belize & Germany & Malta & Sudan \\
\hline Benin & Ghana & Mauritania* $^{*}$ & Swaziland \\
\hline Bolivia & Greece & Mauritius & Sweden \\
\hline Botswana & Grenada & Mexico & Switzerland \\
\hline Bulgaria & Guatemala & Mongolia & Syria \\
\hline Burkina Faso* & Guinea* $^{*}$ & Morocco & Tajikistan \\
\hline Burundi & Guinea-Bissau & Namibia & Tanzania \\
\hline Cambodia & Guyana $^{*}$ & Nepal & Thailand \\
\hline Cameroon & Haiti & Netherlands & Togo \\
\hline Canada & Honduras & New Zealand & Tonga \\
\hline Cape Verde & Hong Kong & Nicaragua & Trinidad \& Tobago \\
\hline Central African Rep. & Hungary & Niger & Tunisia \\
\hline Chad & Iceland & Norway & Turkey \\
\hline Chile & India & Oman & Uganda \\
\hline China & Indonesia & Pakistan & Ukraine \\
\hline Colombia & Iran & Panama & United Kingdom \\
\hline Comoros $^{*}$ & Ireland & Papua New Guinea & United State \\
\hline Congo, Rep. & Israel & Paraguay & Uruguay \\
\hline Costa Rica & Italy & Peru & Venezuela \\
\hline Croatia & Jamaica & Philippines & Vietnam \\
\hline Cyprus & Japan & Poland & Yemen, Rep. \\
\hline Czech Rep. & Jordan & Portugal & Zambia \\
\hline Denmark & Kazakhstan & Romania & Zimbabwe \\
\hline
\end{tabular}

Note: 148 countries. ${ }^{*}$ indicates that the country has only zero FDI flows. 